effect of biologics on joint damage has not translated into a clear-cut decreased need for joint sacrificing surgery as observed in several RA populations.

After 15 years of follow-up, $29 \%$ of the PsA patients had received surgery.

Table 1. Incidence of any joint surgery and joint sacrificing surgery in each calendar period and calculated incidence rate ratios

\begin{tabular}{|c|c|c|c|c|c|c|c|}
\hline \multirow[t]{2}{*}{$\begin{array}{l}\text { Calendar } \\
\text { period }\end{array}$} & \multicolumn{2}{|c|}{$\begin{array}{c}\text { Any joint } \\
\text { surgeries, } n \\
\text { (Joint sacrificing } \\
\text { as first surgery, } \\
\text { n) }\end{array}$} & \multicolumn{2}{|c|}{$\begin{array}{c}\text { Person years, } \\
\text { pyrs }\end{array}$} & \multicolumn{2}{|c|}{$\begin{array}{l}\text { Incidence rate per } \\
1000 \text { pyrs ( } 95 \% \\
\text { Cl) }\end{array}$} & $\begin{array}{c}\text { Incidence } \\
\text { rate ratio } \\
(95 \% \mathrm{Cl}) \\
\text { comparing } \\
\text { PsA with } \\
\text { GPC as } \\
\text { reference in } \\
\text { each } \\
\text { calendar } \\
\text { period }\end{array}$ \\
\hline & PsA & GPC & PsA & GPC & PsA & GPC & $\begin{array}{c}\text { PsA vs } \\
\text { GPC }\end{array}$ \\
\hline $1996-2000$ & $\begin{array}{l}145 \\
(56)\end{array}$ & $\begin{array}{c}536 \\
(180)\end{array}$ & 7966 & 74092 & $\begin{array}{r}18.2 \\
(15.4- \\
21.4)\end{array}$ & $\begin{array}{c}7.2 \\
(6.6-7.9)\end{array}$ & $\begin{array}{c}2.4 \\
(2.0-2.9)\end{array}$ \\
\hline $2001-2004$ & $\begin{array}{l}160 \\
(76)\end{array}$ & $\begin{array}{c}643 \\
(198)\end{array}$ & 7572 & 70850 & $\begin{array}{l}21.1 \\
(18.0- \\
24.7)\end{array}$ & $\begin{array}{c}9.1 \\
(8.4-9.8)\end{array}$ & $\begin{array}{c}2.3 \\
(1.9-2.7)\end{array}$ \\
\hline $2005-2008$ & $\begin{array}{c}264 \\
(100)\end{array}$ & $\begin{array}{l}1261 \\
(389)\end{array}$ & 12128 & 115197 & $\begin{array}{l}21.7 \\
(19.2- \\
24.6)\end{array}$ & $\begin{array}{c}11.0 \\
(10.4- \\
11.6)\end{array}$ & $\begin{array}{c}2.0 \\
(1.7-2.3)\end{array}$ \\
\hline $2009-2012$ & $\begin{array}{c}316 \\
(122)\end{array}$ & $\begin{array}{l}1536 \\
(467)\end{array}$ & 14921 & 143524 & $\begin{array}{l}21.1 \\
(18.9- \\
23.7)\end{array}$ & $\begin{array}{c}10.7 \\
(10.2- \\
11.3)\end{array}$ & $\begin{array}{c}2.0 \\
(1.7-2.2)\end{array}$ \\
\hline
\end{tabular}

Abbreviations: n, number. Cl 95\%, 95\% confidence interval. Ref, reference.

Disclosure of Interests: : Jørgen Guldberg-Møller Paid instructor for: Abbvie, Eli Lilly, BK Ultrasound., René Cordtz: None declared, Lars Erik Kristensen Grant/research support from: UCB, Biogen, Janssen Pharmaceuticals, and Novartis, Consultant for: Consultant for AbbVie, Amgen, Biogen, BMS, Celgene, Eli Lilly, Janssen Pharmaceuticals, MSD, Novartis, Pfizer, Roche, Sanofi, and UCB Pharma., Speakers bureau: Pfizer, AbbVie, Amgen, UCB, BMS, Biogen, MSD, Novartis, Eli Lilly and Company, and Janssen Pharmaceuticals, Lene Dreyer Consultant for: MSD, UCB and Janssen Pharmaceuticals, Speakers bureau: MSD, UCB and Janssen Pharmaceuticals, Speakers bureau: UCB, MSD, Eli Lilly and Janssen Pharmaceuticals.

DOI: 10.1136/annrheumdis-2019-eular.1432

\section{FRI0674 THE ASSOCIATION BETWEEN JOINT EROSIONS PLUS AUTOANTIBODY POSITIVITY AT INITIATION OF METHOTREXATE OR BIOLOGIC THERAPY FOR RHEUMATOID ARTHRITIS AND DISEASE ACTIVITY AND DISABILITY OVER ONE YEAR}

James Gwinnutt ${ }^{1}$, Kimme Hyrich ${ }^{1,2}$, Mark Lunt ${ }^{1}$, Darren Plant ${ }^{3}$, Nisha Nair ${ }^{3}$, Anne Barton ${ }^{2,3}$, Suzanne Verstappen ${ }^{1,2}$, RAMS and BRAGGSS co-investigators. ${ }^{1}$ Arthritis Research UK Centre for Epidemiology, Centre for Musculoskeletal Research, Faculty of Biology, Medicine and Health, University of Manchester, Manchester, United Kingdom; ${ }^{2}$ NIHR Manchester Biomedical Research Centre, Central Manchester University Hospitals NHS Foundation Trust, Manchester Academic Health Science Centre, Manchester, United Kingdom; ${ }^{3}$ Arthritis Research UK Centre for Genetics and Genomics. Centre for Musculoskeletal Research, Faculty of Biology, Medicine and Health, University of Manchester, Manchester, United Kingdom

Background: Joint erosions and autoantibody positivity (rheumatoid factor [RF], anti-cyclic citrullinated peptide antibody [anti-CCP]) predict poor outcomes in patients with rheumatoid arthritis (RA). There are limited data on the combination of these factors and clinical and patient reported outcomes over time.

Objectives: To compare the disease activity and disability over 1 year of those with poor prognostic factors at treatment initiation (methotrexate [MTX] or biologics) to those without.

Methods: Patients were recruited to 1 of 2 UK-based multi-centre prospective cohort studies: MTX-starters: Rheumatoid Arthritis Medication Study (RAMS); biologic-starters: Biologics in Rheumatoid Arthritis Genetics and Genomics Study Syndicate (BRAGGSS). Anti-CCP (Axis-Shield Anti$\mathrm{CCP}$ test; U/ml; anti-CCP titre $>5 \mathrm{U} / \mathrm{ml}=$ anti-CCP+)/RF (Beckman
Coulter AU5400, RF latex assay; IU/ml; RF titre $>14 \mathrm{IU} / \mathrm{ml}=\mathrm{RF}+$ ) status were determined from baseline $(\mathrm{BL})$ blood samples at the co-ordinating centre; erosions (yes/no) were recorded from medical notes. Missing data resulting from anti-CCP assay failure were imputed using multiple imputation. Patients who were anti-CCP+ and/or RF+ and had erosions were classified as having poor prognosis (PP); all other patients were classified as not having poor prognosis (NPP). Patients completed the Health Assessment Questionnaire (HAQ) and the Disease Activity Score (DAS28) was calculated at BL, 6 months and 12 months. The DAS28 and HAQ scores of the prognostic groups were compared at each assessment using linear regression, adjusted for age, gender and disease duration.

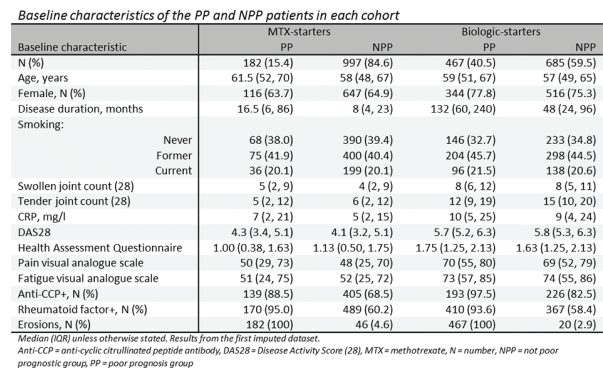

Results: In total, 1179 (PP = 182 [15.4\%]) MTX-starters and 1152 (PP = $467[40.5 \%])$ biologic-starters were included (BL characteristics in Table). For MTX-starters, PP and NPP patients had similar DAS28, whereas for biologic-starters, PP patients had lower DAS28 compared to NPP patients after baseline (adjusted mean difference [95\% CI]: MTX-starters BL $=0.1$ $[-0.1,0.3] ; 6$ months $=-0.1[-0.3,0.2] ; 12$ months $=-0.1[-0.4,0.2] ;$ biologic-starters $\mathrm{BL}=-0.1[-0.2,0.0] ; 6$ months $=-0.2[-0.4,0.0] ; 12$ months $=-0.4[-0.6,-0.1])$. HAQ scores were similar between PP and NPP patients in both cohorts (adjusted mean difference [95\% Cl]: MTX-starters $\mathrm{BL}=0.08[-0.04,0.20] ; 6$ months $=0.02[-0.11,0.15] ; 12$ months $=$ $0.03[-0.17,0.10]$; biologic-starters $\mathrm{BL}=0.00[-0.09,0.08] ; 6$ months $=$ $0.00[-0.12,0.13] ; 12$ months $=0.01[-0.14,0.16]$ ).

Conclusion: PP and NPP MTX-starters had similar outcomes. For biologic-starters, PP patients had lower disease activity after baseline; knowledge of these prognostic factors may have prompted more intensive assessment of PP patients after starting treatment.

Disclosure of Interests: James Gwinnutt: None declared, Kimme Hyrich Grant/research support from: Grants to institution: BMS, Pfizer, UCB Mark Lunt: None declared, Darren Plant: None declared, Nisha Nair None declared, Anne Barton: None declared, Suzanne Verstappen: None declared

DOI: 10.1136/annrheumdis-2019-eular.4586

\section{FRI0675 AUTOIMMUNE PERIPHERAL ULCERATIVE KERATITIS ASSOCIATED ETIOLOGY, CLINICAL CHARACTERISTICS, TREATMENT AND VISUAL PROGNOSIS}

Claudia Hubbe-Tena ${ }^{1}$, Mariana Fernandez ${ }^{1}$, Ned Merari Davila-Avila ${ }^{1}$,

Rashel Cheja ${ }^{1}$, Pablo León-Oritz ${ }^{2}$, Luz Elena Concha ${ }^{1} .{ }^{1}$ Asociación para Evitar la Cegura en México, Ciudad de México, Mexico; ${ }^{2}$ Instituto Nacional de Neurología y Neurocirugía "Manuel Velasco Suárez", Ciudad de México, Mexico

Background: Peripheral ulcerative keratitis (PUK), a rare sight-threatening condition, is an inflammatory corneal disease with an estimated incidence of 8 to 10 cases per million. PUK is characterized by the presence of an epithelial defect with progressive stromal corneal degradation and juxtalimbal thinning.

Objectives: To describe the associated etiology, demographic and clinical characteristics, treatment and visual prognosis of patients with PUK and autoimmune disease.

Methods: A retrospective, transversal, descriptive, observational cohort study was performed. The clinical file of all patients that had been diagnosed with PUK at the Inflammatory Eye Disease Clinic and who came to a follow-up appointment between January 2014 through February 2018 was evaluated. With a minimum follow-up of 6 months since PUK diagnosis.

Quantitative data was calculated in terms of means and standard deviations. Qualitative data in frequencies. Chi-square and rank sum tests were used to compare groups. Kaplan-Meier methods to estimate survival 
rates according to treatment. Comparisons of survival rates between treatments were performed using log-rank tests. A $p$ level of $<0.05$ was considered significant. Statistical analyses were performed using SPSS 24.0 Results: A total of 109 patients (155 eyes; 79.8\% female; mean age $53.9 \pm 12.5$ (23 to 81 ) years) were included. The frequency of the association between PUK and an autoimmune systemic disease, was $86.3 \%$ (94). The leading etiology was RA (52.3\%; $n=57)$; VAA $(30.3 \% ; n=33)$, being GPA the foremost recognized in this group $(84.8 \% ; 28 / 33)$. Other were SLE, PSS, JIA, and ReA.

When PUK started, RA was already diagnosed in $87.7 \%(50 / 57) ; 18.2 \%$ $(6 / 33)$ of AAV. Mean disease evolution in RA was $15 \pm 8.2$ years; AAV had $3.9 \pm 5.6$ years $(p=0.05) .29 \%(n=17)$ of RA untreated; only 4 $(12.2 \%)$ AAV were immunosuppressed by the time PUK settled.

Systemic autoimmune activity, was found in $31.5 \%(18 / 57)$ of RA and $90.9(30 / 33)$ of AAV. Arthralgia was foremost referred by RA $(94.4 \% ; 17 /$ $18)$; ear-nose-throat symptoms were in $\operatorname{AAV}(86.6 \% ; 26 / 30)$. In the latter, some degree of renal dysfunction was found in 33.3\% (10/33).

PUK characteristics in RA and AAV. Moderate (34.2\%) and mild (36.3\%) PUK were more frequently seen in RA; whereas moderate $(36.3 \%)$ and severe $(33.3 \%)$ in AAV $(p=0.016)$. RA associated PUK commonly involved the inferior corneal quadrant $(54.3 \%)$, as AAV the superior one $(73.8 \%$; $p$ $<0.01)$. Corneal perforation was more frequent in RA than AAV $(54.5 \%$ vs $22.7 \%$; $p=0.481$ ); although the risk of perforation associated to RA didn't show statistical significance (OR 1.14 [IC 95\% 0.8 - 1.63]). Necrotizing scleritis was more commonly seen in AAV (RA $n=1$ vs $A A V n=10$. The more frequent instated treatment in RA was oral prednisone combined with oral DMARDs $(31.6 \% ; 18 / 57)$. More aggressive therapy (MPS, CYC or Rituximab) was designated in $22.8 \%(n=13)$. On the other hand, $78.7 \%(26 / 33)$ of AAV were managed with the MPS-pred scheme merged with CYC (36.4\%; $n=12)$ or Methotrexate $(42.4 \% ; n=14)$.

Conclusion: RA and AAV are the more frequent autoimmune diseases that can manifest with PUK. In RA, the lack of arthritis could be mistaken as quiescent, and wrongly undertreated, allowing it to progress to a vasculitic stage. It may impact their life quality if complicated with corneal perforation. In AAV the PUK can be the initial sympton of the disease and is associated with a more sever ocular presentation. Routine ophthalmologic examinations might help the rheumatologist to assess RA and AAV activity and treatment.

\section{REFERENCES:}

[1.] John SL, Morgan K, Tull AB, Holt JL. Eye. 1992;6:630-6.

Disclosure of Interests: None declared

DOI: 10.1136/annrheumdis-2019-eular.8339

\section{FRI0676 PREVALENCE AND UVEITIS CHARACTERISTICS OF A COHORT OF PATIENTS WITH SPONDILOARTROPATHY}

Sycille Jeria ${ }^{1}$, Patricia Moya ${ }^{2}$, Ana Laiz $^{2}$, Jose Vela ${ }^{3}$, Jesus Diaz ${ }^{3}$, Hyesang Park $^{2}$ Berta Magallares ${ }^{2}$, Ivan Castellví ${ }^{2}$, Ana Milena Millán Arciniegas $^{2}$, Josep Maria Llobet ${ }^{2}$, Hector Corominas ${ }^{2}$. 1 HOSPITAL DE LA SANTA CREU Y SANT PAU, RHEUMATOLOGY, BARCELONA, Spain; ${ }^{2}$ HOSPITAL DE LA SANTA CREU Y SANT PAU, BARCELONA, Spain; ${ }^{3}$ HOSPITAL DE LA SANTA CREU Y SANT PAU, Ophthalmology, BARCELONA, Spain

Background: Uveitis can be a clinical manifestation of different systemic processes, known is the association of anterior uveitis in patients with spondyloarthritis ( $\mathrm{SpA})$

Objectives: To describe the prevalence, characteristics and course of ocular inflammatory pathology from a cohort of patients with $\mathrm{SpA}$

Methods: Retrospective descriptive study made in a cohort of $451 \mathrm{SpA}$ patients according to the ASAS classification criteria in a a tertiary university hospital from Barcelona. Were selected patients who presented or had presented uveítis (defined according to the SUN ${ }^{1}$ classification criteria) Demographic, clinical, radiological and serological data of the joint disease and characteristics of the ocular affectation were collected, as well as the treatment of both

Results: Of the 451 patients reviewed, 43 (9.53\%) patients with a history of uveitis were included in the study. From the cohort, the average age at diagnosis of SPA was $37( \pm 27)$ years and $38(88.4 \%)$ had positive HLAB27. The most prevalent subtypes of SPA were Ankylosing Spondylitis (AS): 27 (62.8\%) and Psoriatic Arthritis (APSo): 8 (18.6\%). The characteristics of the sample are summarized in Table 1

The average age at the first uveitis outbreak was $45 \pm 23$ years. The anterior location was more prevalent ( $n$ : 39, 90.7\%), unilateral ( $n$ : 35 , $81.4 \%$ ) and acute onset ( $\mathrm{n}$ : $42,97.6 \%)$
Two of patients with anterior uveítis had other associated complications, one had macular edema and other retinal vasculitis. The treatment of uveitis was topical corticosteroids in 39 (90.6\%) patients, $2(4.6 \%)$ treat ment with oral sulfasalazine. Despite the treatment, $22(51.2 \%)$ patients presented a recurrent course. Table 2 shows the ocular clinical features

Table 1. Clinical characteristics of SpA cohort.

\begin{tabular}{lc}
\hline Sex, $\mathrm{n} \%$ (men/women) & $24 / 19(55.81 / 44.18)$ \\
\hline Diagnoses SpA, years \pm DE & $37 \pm 27$ \\
Subtype SpA, $\mathrm{n}(\%)$ & $27(62.8)$ \\
EA, $\mathrm{n}(\%)$ & $2(4.6)$ \\
Ell, $\mathrm{n}(\%)$ & $8(18.6)$ \\
APSo, $\mathrm{n}(\%)$ & $6(13.9)$ \\
PreRx, $\mathrm{n}(\%)$ & \\
HLAB27, $\mathrm{n}(\%)$ & $38(88,4)$ \\
Affectation SpA & $25(58.1)$ \\
Axial, $\mathrm{n}(\%)$ & $4(9,3)$ \\
Periferic, $\mathrm{n}(\%)$ & $11(25,6)$ \\
Mixed, $\mathrm{n}(\%)$ & \\
Treatment SpA & $14(32)$ \\
FAMEs & $5(11.6)$ \\
Metotrexate, $\mathrm{n}(\%)$ & $2(4.6)$ \\
Sulfasalazine, $\mathrm{n}(\%)$ & $5(11.6)$ \\
Azatioprine, $\mathrm{n}(\%)$ & $9(20)$ \\
Leflunomide, $\mathrm{n}(\%)$ & $17(39.5)$ \\
ANTI- TNF & $6(13.9)$ \\
Etarnecept, $\mathrm{n}(\%)$ & $6(13.9)$ \\
Adalimumab, $\mathrm{n}(\%)$ & $2(4.6)$ \\
Golimumab, $\mathrm{n}(\%)$ & $1(2.3)$ \\
Infliximab, $\mathrm{n}(\%)$ & $2(4.6)$ \\
Certolizumab, $\mathrm{n}(\%)$ & \\
Secukinumab, $\mathrm{n}(\%)$ & \\
Ustekinumab, $\mathrm{n}(\%)$ &
\end{tabular}

Table 2. Clinical characteristics of uveítis from SUN criteria.

\begin{tabular}{lc}
\hline Uveitis, $\mathrm{n}(\%)$ & $43(9,53)$ \\
\hline Age $1^{\circ}$ outbreak, years \pm DE & $45 \pm 23$ \\
Type & $39(90.7)$ \\
Anterior, $\mathrm{n}(\%)$ & $2(4.6)$ \\
Intermedite, $\mathrm{n}(\%)$ & 0 \\
Posterior, $\mathrm{n}(\%)$ & $2(4.6)$ \\
Panuveitis, $\mathrm{n}(\%)$ & \\
Unilateral, $\mathrm{n}(\%)$ & $35(81.4)$ \\
Bilateral, $\mathrm{n}(\%)$ & $8(18.6)$ \\
Onset & $42(97.6)$ \\
Sudden, $\mathrm{n}(\%)$ & $1(2.3)$ \\
Insidious, $\mathrm{n}(\%)$ & $38(88.3)$ \\
Duration & $5(11.6)$ \\
Limited (<=3 meses) $\mathrm{n}(\%)$ & $13(30.2)$ \\
Persistent $(>3$ meses) $\mathrm{n}(\%)$ & $22(51.2)$ \\
Course & $8(18.6)$ \\
Acute ${ }^{*} \mathrm{n}(\%)$ Recurrent ${ }^{* *} \mathrm{n}(\%)$ & \\
Chronic ${ }^{* * *} \mathrm{n}(\%)$ & \\
Treatment Uveitis & $39(90.6)$ \\
Corticosteroids topics, $\mathrm{n}(\%)$ & $2(4.6)$ \\
FAME (sulfasalazine), $\mathrm{n}(\%)$ & \\
\hline * Episode sudden onset and limited duration ${ }^{* *}$ Repeated episodes separated by periods of \\
inactivity without treatment 3 months in duration **Persistent uveitis with relapse in 3
\end{tabular}

months after discontinuing treatmen

Conclusion: In our cohort of SPA, prevalence of uveitis was $10 \%$, predominantly in HLA B27 patients and axial involvement, of which $62.8 \%$ met criteria for $A D$ and $18.6 \%$ APSO with different degrees of axial involvement, including under systemic treatment (FAMEs/Biological). The most frequently presentation was anterior, unilateral, acute and recurrent uveitis. Being the most used treatment topical corticosteroids.

\section{REFERENCES}

[1] Am J Ophthalmol 2005;140: 509-516

[2] Ann Rheum Dis. 2009;68:777-83

Disclosure of Interests: Sycille Jeria: None declared, Patricia Moya: None declared, Ana Laiz Consultant for: Lilly, Novartis, AbbVvie, MSD, UCB and Janssen, Speakers bureau: Lilly, Novartis, Abvvie, MSD, UCB and Janssen, Jose Vela: None declared, Jesus Diaz: None declared, HyeSang Park: None declared, Berta Magallares: None declared, Ivan Castellví Consultant for: I received fees less than 5000USD as a consultan for Kern and Actelion, Paid instructor for: I received fees less than 